\title{
Blood Serum Lead and Cadmium Level Among Pregnant Women in Gas Flaring Communities in Bayelsa State Nigeria.
}

\section{*SOLOMON M. UVOH, Arthur N CHUEMERE, *CHARLES NNAMDI NGAIKEDI, \# KIRIDI EMILY} GABRIEL E.

\author{
*Department of Human Physiology, Faculty of Basic Medical Sciences, College of Health Sciences University of port Harcourt, Rivers State \\ Nigeria. \\ \# Department of Human Physiology, Faculty of Basic Medical Sciences, Niger Delta University, WILBERFORCE Island Bayelsa State Nigeria \\ Corresponding Author: SolomonU31@gmail.com \\ DOI: 10.29322/IJSRP.11.05.2021.p11316 \\ http://dx.doi.org/10.29322/IJSRP.11.05.2021.p11316
}

\begin{abstract}
This research study determines the serum lead and cadmium (ppm) level of pregnant women living in gas flaring communities in Bayelsa State, Nigeria. Two hundred apparently healthy pregnant women and one hundred non-pregnant as control were randomly selected as participants for this study. The prevalence of elevated serum lead ( $>0.1 \mathrm{ppm})$ above the world health organization permissible range among the non-pregnant and pregnant subjects was (2\%) and (5\%) while that of cadmium $(>0.0012 \mathrm{ppm})$ was $(11.33 \%)$ and $(19.66 \%)$ respectively. However the total prevalence of elevated heavy metals in the blood of non-pregnant and pregnant subjects was $(6.66 \%)$ and $(12.33 \%)$. The study reveal a non-significant increased concentration of Lead level among the non-pregnant control group $(0.07 \mathrm{ppm})$ to that of the pregnant test $(0.05 \mathrm{ppm})$ with no difference in their cadmium $(0.01 \mathrm{ppm})$ level. The study reveal a non-significant slight increase in the level of Lead among the pregnant test group $(0.06 \mathrm{ppm})$ during their third trimester when compared with those in their first and second trimesters $(0.05 \mathrm{ppm})$ with a cadmium blood level of (0.02ppm) among those in their third trimester.
\end{abstract}

Keyword: Lead, Cadmium, Pregnancy, Serum, Blood pressure, Trimesters

\section{INTRODUCTION}

Lead is a naturally occurring metal found in the environment and earth crust. The activities of man such as mining, and the burning of fossil fuels discharged lead into our environment. The human body cannot use lead but rather stores it like calcium in the bones, teeth etc.(Navas et al, 2007); Maternal exposure to lead, cadmium and its subsequent absorption into the blood stream through the gastrointestinal tract may be either through food, soil, dust, water from the environmental. Lead crosses the placenta blood barrier to the unborn child to cause miscarriage, premature birth, stillbirth, low birth weight, severe brain damage, and nervous system disorder. This is because they absorb lead faster than adults. (WHO 2016).Studies also indicate that mothers with significant level of cadmium had significant increase in both systolic and diastolic blood pressure (Erebi et al, 2013; Nilima et al, 2011). Cardiovascular disease also known as the epidemiology due to its rapidity and frequency with its implication to public 
health in this our $21^{\text {st }}$ Century has been investigated by many epidemiological studies and the results from those studies shows the negative effect of lead and other heavy metals on mortality of cardiovascular diseases (Peter 2012). The long term effect of lead poisoning can result in irreversible nephropathy, cognitive difficulties with extended electroencephalogram pattern and encephalopathy in the nervous system. Reduction in the synthesis of heam and anemia also result in high level exposure to lead (Hernbery et al, 1970). The effect of lead on renal impairment can result in proximal tubular dysfunction and changes in ultrastructural architecture to either chronic nephropathy or kidney failure (Goyer, 1971). The exposure to lead has been shown to cause a deficiency of nitric oxide and its relaxing endothelial effects thereby resulting in high blood pressure. Severe exposure to leads thus results in the exaggeration of the sympathetic nerve tone activities with norepinephrine plasma level increase (Tsao et al, 2000). Evidence from previous studies have shown cadmium as a strong initiator of atherosclerosis and progression by increasing blood pressure or damages through the kidneys (Satarug et al 2006 and Hwangbo et al 2011).

\section{MATERIALS AND METHODS}

Location of Study; gas flaring communities and its environs in Yenagoa, Ogbia, Southern Ijaw local government area of Bayelsa State Nigeria.

Sample of Study Population; A total of two hundred pregnant and one hundred non- pregnant women were randomly selected from Tombia, Obuna, Polakau, Okolobiri, Immiringi etc. as research test groups and control subjects for the research study. The subjects must have lived in their respective communities consistently within Bayelsa State for at least five years.

Analysis: The results were analyzed using statistical packaging for social sciences (SPSS) version 20.0.

Sources of Data; The Primary data were collected from the subjects directly in government health centers located in their respective communities located within the state.

\section{Determination of blood cadmium and lead concentration}

Heavy metal analysis was conducted using Varian AA240 Atomic Absorption Spectrophotometer according to the method of APHA 1995 (American Public Health Association) at Springboard research laboratories Awka Anambra State Nigeria.

Working principle: Atomic absorption spectrometer's working principle is based on the sample being aspirated into the flame and atomized when the AAS's light beam is directed through the flame into the monochromatic, and into the detector that measures the amount of light absorbed by the atomized element in the flame. Since metals have their own characteristic absorption wavelength, a source lamp composed of that element is used, making the method relatively free from spectral or radiation interferences. The amount of energy of the characteristic wavelength absorbed in the flame is proportional to the concentration of the element in the sample.

Ethical Consideration: The research was duly approved by the Bayelsa state ministry of Health ethical committee, with approval number BSHREC/Voi,1/20/1. 


\section{RESULTS}

Table 1: Blood serum concentration of lead and cadmium of the study population

\begin{tabular}{|c|c|c|c|c|c|c|c|c|}
\hline \multirow[t]{3}{*}{ Parameters } & \multirow[t]{2}{*}{ Non-pregnant } & \multicolumn{6}{|c|}{ Pregnancy in Trimesters } & \multirow[b]{2}{*}{$\begin{array}{l}\text { Anova } \\
\text { Sig. }\end{array}$} \\
\hline & & $1^{\text {st }}$ Trimester & $\begin{array}{l}\% \\
\text { diff }\end{array}$ & $2^{\text {nd }}$ Trimester & $\%$ diff & $3^{\text {rd }}$ Trimester & $\%$ diff & \\
\hline & $\mathrm{N}=100$ & $\mathrm{~N}=19$ & & $\mathrm{~N}=90$ & & $\mathrm{~N}=91$ & & \\
\hline $\mathrm{Pb}$ (ppm) & $\begin{array}{l}0.07 \pm 0.21 \\
(0.00-1.58)\end{array}$ & $\begin{array}{l}0.05 \pm 0.09 \\
(0.00-0.40)\end{array}$ & 28.5 & $\begin{array}{l}0.05 \pm 0.12 \\
(0.00-0.80)\end{array}$ & 28.5 & $\begin{array}{l}0.06 \pm 0.14 \\
(0.00-0.80)\end{array}$ & 14.2 & $\begin{array}{l}0.16 \text { not } \\
\text { sig }\end{array}$ \\
\hline Cd (ppm) & $\begin{array}{l}0.01 \pm 0.02 \\
(0.00-0.07)\end{array}$ & $\begin{array}{l}0.01 \pm 0.01 \\
(0.00-0.03)\end{array}$ & 0 & $\begin{array}{l}0.01 \pm 0.01 \\
(0.00-0.08)\end{array}$ & 0 & $\begin{array}{l}0.02 \pm 0.06 \\
(0.00-0.68)\end{array}$ & 50 & $0.00 \mathrm{sig}$. \\
\hline
\end{tabular}

NB: Results are given as mean \pm standard deviation and range in parenthesis.

Table 2: Relationship between serum lead and cadmium level and age in pregnancy

\begin{tabular}{llllll}
\hline Parameters & $<$ 21yrs & 21-30yrs & 31-40yrs & 41-50yrs $(\mathbf{n = 2})$ & Anova sig. \\
& $(\mathbf{n = 1 9 )}$ & $(\mathbf{n = 1 1 6})$ & $(\mathbf{n}=\mathbf{6 3})$ & $\mathbf{P}=<\mathbf{0 . 0 5}$ \\
\hline $\mathbf{P b}(\mathbf{p p m})$ & $0.05 \pm 0.09$ & $0.05 \pm 0.14$ & $0.05 \pm 0.13$ & $0.06 \pm 0.12$ & 0.94 \\
$\mathbf{C d}(\mathbf{p p m})$ & $0.01 \pm 0.02$ & $0.01 \pm 0.02$ & $0.01 \pm 0.01$ & $0.06 \pm 0.20$ & $0.00 \#$
\end{tabular}

NB: Results are given as mean \pm standard deviation \# significant.

Table3: prevalence of elevated lead and cadmium in non-pregnant and pregnant subjects

\begin{tabular}{lllll}
\hline Parameters & \multicolumn{2}{l}{ Non pregnant } & \multicolumn{2}{l}{ Pregnant } \\
\cline { 2 - 5 } & permissible & High & permissible & High \\
& No $(\%)$ & No $(\%)$ & No $(\%)$ & No $(\%)$ \\
Lead $(\mathrm{ppm})$ & $94(31.33)$ & $6(2)$ & $185(61.66)$ & $15(5)$ \\
\hline
\end{tabular}




\begin{tabular}{lllll}
\hline Cadmium & $66(22)$ & $34(11.33)$ & $141(47)$ & $59(19.66)$ \\
$(\mathrm{ppm})$ & & & & \\
Total mean no & $160(26.66)$ & $40(6.66)$ & $326(54.33)$ & $74(12.33)$ \\
$(\%)$ & & & \\
\hline
\end{tabular}

NB: permissible range for lead $=0.1 \mathrm{ppm}$ and cadmium $=0.0003-0.0012 \mathrm{ppm}$

\section{DISCUSSION}

The result from the study reveal a non-significant increased concentration of Lead level among the non-pregnant control group $(0.07 \mathrm{ppm})$ to that of the pregnant test $(0.05 \mathrm{ppm})$ with no difference in their cadmium $(0.01 \mathrm{ppm})$ level. However we observed a non-significant slight increase in the level of Lead among the pregnant test group (0.06ppm) during their third trimester when compared with those in their first and second trimesters $(0.05 \mathrm{ppm})$ with a cadmium blood level of $(0.02 \mathrm{ppm})$ among those in their third trimester. We noticed a link between the age of the pregnant test group with Lead and cadmium among those within the ages of forty one to fifty years $(0.06 \mathrm{ppm})$ each when compared with the younger adults that are less than twenty one to forty years of age $(0.05 \mathrm{ppm} \mathrm{Pb}$ and $0.01 \mathrm{ppm} \mathrm{Cd})$.A similar observation was also noticed among those in their third trimesters $(0.09 \mathrm{ppm}$ and $0.02 \mathrm{ppm})$ when compared with the first and second trimesters $(0.05 \mathrm{ppm}$ and $0.01 \mathrm{ppm})$ respectively. The non-pregnant and the pregnant group who depend regularly on carbohydrate (cassava) dietary food had higher serum Lead (0.07) and cadmium $(0.01 \mathrm{ppm})(0.05 \mathrm{ppm})(0.01 \mathrm{ppm})$ than those subjects that depend on other dietary food. Though the serum level of Lead was not above the World Health Organization permissible (WHO 2007) range acceptable in the blood pegged at 10 $\mu \mathrm{g} / \mathrm{dL}(0.1 \mathrm{ppm}) \mathrm{Lead}$ and 0.03 to $0.12 \mu \mathrm{g} / \mathrm{dl}(0.0003 \mathrm{ppm}$ to $0.0012 \mathrm{ppm})$ for cadmium. The level of blood cadmium of the non-pregnant control and the pregnant test group were all above the World Health Organization range that the body can tolerate compared to our findings of (0.01ppm and 0.06ppm).The blood cadmium level results is not consistent with the findings of Ifenkwe John et al (2018) who observed 0.03ppm from his study in Bayelsa state gas flaring communities. Women with history of abortion and infertility have been linked with high level of blood cadmium because the metal is capable of altering the normal Physiology of reproductive hormones when it accumulate in the granulossa cells of the ovaries and membrane of the pituitary gland to cause a significant reduction in the binding of gonadotropin and dysfunction of folliculogenesis.Prolonged exposure to gas flares have also be linked with preterm birth and low birth weight (Durska et al 2001, USC 2020,and Hidekuni Inadera 2020).

Consumption of certain dietary food grown in soil contaminated with cadmium and smokes from cigarette and tobacco, gas flares are all contributing factors responsible to the development of increase blood cadmium level which can result to serious kidney, lung and bone disorder known as Itai-Itai disease in women mainly (Kobayashi et al 2006 and Ezaki et al 2003).

\section{CONCLUSION}

The serum lead level among the non-pregnant was higher than the pregnant test group with no significant ( $\mathrm{p}$-value ( $>0.05)$ but there was a significant increase in serum cadmium level above the world health organization bench mark among the pregnant test 
group according to trimesters and age compared with the non-pregnant control group. The prevalence of elevated serum lead above the world health organization permissible range among the non-pregnant and pregnant subjects was (2\%) and (5\%) while that of cadmium was $(11.33 \%)$ and $(19.66 \%)$ respectively.

\section{REFERENCES}

Angs H Sarka, Geethanjali Ravindran (2013). A brief review on the effect of cadmium toxicity: from cellular to organ Level. B IT \& Pilani Goa 403726 India WHO (2012) maternal mortality WHO Geneva.

Davison J.M, sheills E.A, Philips PR, lindheimer M.D (1988).Serial evaluation of vasopressin release and thirst in human pregnancy .J. clin Invest. 81-798.

Dettoni J.L, Consolim F.M, Drager L.F, Rubira M.C (2012). Cardiovascular effect of partial sleep deprivation in healthy Volunteers. Journal of applied physiology vol. 113 (2):232-2366.

Durska G,Stezenie Olowiu,Kadimu W.O,Noworodkow O (2001). Level of lead and cadmium in pregnant women and newborns and evaluation of their impact on child development. Ann Acad Med stetin 47;49-60.Polish.PMID;12514901.

Erebi P. Ikeh-Tawari, John I Anetor, Charles Davies (2013). Cadmium level in pregnancy, influence on neonatal Birth alt and possible Amelioration by some essential trale elements. International Journal of toxicology vol 20 (1) 3702118.

Fabio P. A Lourenco A.S, Hello B.S, Marcos V>T, Nilo B. (2016). Bioaccumulation of mercury, cadmium, Zinc, Chromium, and lead in muscle, liver and spleen tissues of a large commercially valuable catfish species in Brazil. Anas of the Brazilian Academy Sci 88(1): 137-147 Huhon M (1987). Human health concerns of lead, mercury, Cadmium and arsenic. Monitoring and assessment research center Kings college, London 459A Pulham Road UK.

Farhan Abdul R (2014). Lead poisoning Effects on pregnant women and children. Public health physician/researcher, our own public Health institute, Karachi Pakistan.

Goyer R.A(1971). Lead and the Kidney, current topics in pathology, Vol.55p.147-176.

Hernbery’s, and Nikannen J(1970). Enzyme Inhibition by lead under normal urban conditions. Lacet 1, 63-64.

Hidekuni Inadera (2020).Association of blood cadmium levels in pregnant women with infant birth size and small for gestational age infants;the Japan environmental and children study group.vol 191,110007.

Hwangbo Y,Weaver V.M,Tellez-plaza M,Guallar E,Lee B.K, Navas -Acien A (2011).Blood pressure cadmium and estimated glomerular filtration rate in Korean adults.PMC free articles 119 (12):1800-1805.

Idodo- Umeh E (2012). Bioaccumulation of heavy metals in cassava tubers and plantain fruits grown in soil impacted with petroleum activities Research Journal of environmental sci Vol.4:33-41

John Ifenkwe C,Nwajo Harrison U,Cherechi Nwosu, Solomon Ederi A (2018).Heavy metals bioaccumulation and lipid peroxidation damage in residence of a gas flaring Community. International journal of advances in Scientific research and engineering. Volume 4 (7); 140-151 
Karen Melchiorre, Rajan Shama, Asma Khalil, Baskaran Milasanathan (2016). Maternal cardiovascular findings in normal pregnancy Dept. of obstetrics \& gynecology St. George University of London. UK.

Kingdierski W.D (2000). Importance of human environmental exposure to hazardous air pollutants from flares environment review Vol.8:41-62.

Missoun F., Slimeni M, Aoues A, (2009), Toxic effect of lead on kidney function in rat wistar. African Journal of Biochemistry Research vol 4 (2), pp. 21-27.

Nadmitove B.H, Kangs,Chu J.M, Khim J.S (2015). Large scale monitoring and addeddment of metal contamination in surface water of the Selenga River Basin. Environ. Sci. Pollution Res. Int 22 (4): 2856-2867.

Navas A, Guala E, Silbergeid E.K, Rothenberg (2007). Lead exposure and cardiovascular disease. A systematic review, Environmental health perspective, Vol.115, No 3 pp 472-482

Nilima N, Dongre, Adinath N. Soryaka, Arun J. patis, Ambekar G, Dillep B. Rathi (2011). Biochemical effect of lead exposure on systolic \& diastolic Blood pressure and hematological parameters in North Karnataka. Indian Journal of clinical Biochemistry 26 (4): 400-406.

Nishijo M, Nakagawa H, Honda R, Tonebik etal (2002). Effect of maternal exposure to cadmium on pregnancy outcome \& breast milk. Occup. Environ. Med 59-394-6

Nulenkwo C.N, Ogagarve D.O(2011). Effect of gas flaming on surface and ground water in Delta state Nigeria Journal of Geology and mining research vol 3(5): 131-136

Olsson K. (1986). Pregnancy - A Challenge to water balance. New physio Sci., 1:131.

Otebhi E.G, Osadolor H.B (2016), Select toxic metal status of pregnant women with history of pregnancy complications in Benin city South Nigeria Journal of Applied Sci \& Environmental Management vol 20 (1) 5-10

Patrick L. (2006).Lead toxicity part II: the role of free radical damage and the use of antioxidants in the pathology and treatment of lead toxicity. Alternative Medicine review, Vol: II, No 2,pp 114-127.

Peter Jennrich (2012). The influence of ansenic, Lead, and Mercury on the development of cardiovascular disease (ISRn) Hypertension, Hindaw Publishing corporation Vol. 2013, article ID 234034 P15.

Ribarov S.R and Benov L.C (1981). Relationship between the hemolytic action of heavy metals and Lipid peroxidation. Bioclinical at Biophysical acta, Vol. 640,No. 3 pp 721-726.

Satarug S,Nishijo M,Lasker J.M,Edward R.J,Moore M.R (2006).Kidney dysfunction and hypertension;role for cadmium,p450 and heme oygenases?The Tohoku journal of experimental medicine 208(3):179-202.

Sohyae L,Jin-young M, Kyoung-bok M(2020).Female infertility associated with blood lead and cadmium levels.International journal of Environmental research and public health 17 (5);1794 
Olalekan Rm, Adedoyin O, Odubo TV (2019). Measures of harm from heavy metal contents (lead and cadmium) in women lipsticks and lipglosses in Yenagoa metropolis Bayelsa State, Nigeria. International Journal of petrochemistry and research $\left.1 \mathrm{ss}^{\wedge}\right): 2638-1974$

Tsao D.A, YU H.S, Cheng J.T, HOCK, change H.R (2000). The change of Beta adrenergic system in lead induced hypertension. Toxicity and applied Pharmacology Nol.164 No, 2 pp 127-133

World health (2007).Heavy metals from long range trans-boundary air population. Copenhagen world health organization regional office for Europe pp 40-45 available for http//www.euro.who.int/document/e91044 pdf.

World health organization (2016), WHO global urban ambient air pollution database available online. 